\title{
BARIERY I SZANSE RODZICIELSTWA ZASTĘPCZEGO. RODZINA ZASTĘPCZA RECEPTĄ NA KRYZYS?
}

W dyskursie społecznym coraz częściej pojawiają się sformułowania dotyczące spraw dzieci. Należą do nich przede wszystkim szeroko pojęty „interes dziecka”, „dobro dziecka”, „prawa dziecka”, „wsparcie dziecka i rodziny”. Mimo zwiększonego zainteresowania sytuacją dziecka oraz jego rodziny nadal wzrasta liczba dzieci oczekujących na pomoc i wsparcie państwa oraz instytucji mających na celu zapobieganie sytuacjom, w których bezbronne dziecko ponosi konsekwencje występowania dysfunkcji w swojej rodzinie. Rodzina, a przede wszystkim rodzice, sprawują podstawową formę opieki na dzieckiem. Poprzez członków rodziny, przekazywany, podtrzymywany i reprodukowany jest ład społeczny. To rodzina jest podstawową instytucją społeczeństwa zapewniającą mu spójność, ciągłość i trwanie, jest to sfera, w której przez członków rodziny, przekazywany, podtrzymywany i reprodukowany jest ład społeczny [Jamrozik, Nocella 2000: 153]. Rodziny, które z różnych przyczyn nie są w stanie spełniać prawidłowo przypisanych im funkcji, a zwłaszcza funkcji opiekuńczo-wychowawczej są postrzegane jako dysfunkcjonalne, niezdolne do utrzymania spójności rodziny i życia zgodnie z przyjętymi normami i rolami rodzinnymi. Nie każda rodzina kształtuje i przekazuje dziecku prawidłowe wartości, uczy zasad współżycia społecznego, zabezpiecza potrzeby bezpieczeństwa, afiliacji, szacunku, uznania oraz samorealizacji. Dlatego też, gdy role te są pełnione w sposób uznawany za nieodpowiedni bądź wcale - państwo za pomocą różnych instytucji, $w$ tym rodzin zastępczych, przejmuje funkcje rodziny, aby zapewnić dziecku bezpieczeństwo i warunki do stabilnego rozwoju, a jednocześnie zapobiega dziedziczeniu dysfunkcji rodzinnej w przyszłości. Celem artykułu jest zobrazowanie doniosłej roli rodzica zastępczego dla dziecka znajdującego się pod ich opieką, gdyż to rodzina zastępcza kształtuje często przyszłość swoich wychowanków. Zaprezentowane zostaną możliwości, wynikające z wprowadzenia ustawy o wspieraniu rodziny i systemie pieczy zastępczej 1 stycznia 2012 roku [Ustawa 2011]. Rola rodzica zastępczego jest w dalszym ciągu nie- 
doceniona przez społeczeństwo i w konsekwencji pojawia się wiele problemów i trudności wynikających z bycia rodziną zastępczą, a to z kolei wpływa na funkcjonowanie danej rodziny.

Fundamentem systemu opieki jest właściwe prawo, które opiera się na idei partnerstwa z rodzicami, świadomej konieczności wspierania rodzin, ale także potrzeb i możliwości profesjonalistów pracujących z dziećmi, jak również rodzin zastępczych. Istotne jest również to, aby zapewnić dzieciom i młodym ludziom wysoką jakość opieki zastępczej, która zwiększać będzie szanse na pozytywne wyniki [Colton 2001: 181]. Rodzina zastępcza, to instytucja pieczy zastępczej. Jest ona rozwiązaniem tymczasowym, a

\begin{abstract}
utworzone rodziny zastępcze nie powodują powstania więzi rodzinno-prawnej pomiędzy rodzicami zastępczymi a dzieckiem, tak jak to się dzieje przy adopcji. Dziecko przyjęte do rodziny zastępczej nie uzyskuje statusu dziecka rodziców zastępczych. Pomiędzy dzieckiem a rodzicami zastępczymi nie powstają obowiązki i uprawnienia alimentacyjne, nie dochodzi pomiędzy nimi do dziedziczenia z mocy ustawy. Od adopcji odróżnia rodzinę zastępczą również to, że wraz z jej utworzeniem nie ulega zmianie stan cywilny umieszczonego w niej dziecka. Rodzice zastępczy nie przejmują też nigdy pełnej władzy rodzicielskiej nad przyjętymi do siebie dziećmi. W odróżnieniu od osób adoptujących rodzice zastępczy w wypełnianiu swych zadań podlegają nadzorowi [Andrzejewski 1999b: 85].
\end{abstract}

Ustawodawstwo polskie w coraz większym stopniu koncentruje się na ochronie i egzekwowaniu realizacji praw dziecka. Zapisy ustawy o wspieraniu rodziny i systemie pieczy zastępczej dotyczą tworzenia systemu pomocy rodzinie, w tym także dysfunkcjonalnej. Celem głównym ustawy jest zapewnienie dziecku takich warunków, które umożliwią mu pozostanie w rodzinie biologicznej. W sytuacjach, w których nie będzie to możliwe, ustawa przewiduje rozwinięcie systemu pieczy zastępczej przez rodzinną pieczę zastępczą (rodziny zastępcze) i instytucjonalną. Stąd też w ostatnim czasie wzrasta społeczne zainteresowanie problematyką rodzin zastępczych. U jego podłoża leży głębokie przekonanie, że rodzina zastępcza, obok rodziny naturalnej, jest najlepszym i najbardziej skutecznym miejscem do wychowywania dzieci. Jednak zbyt mało mówi się o barierach, trudnościach i problemach, jakie wiążą się z funkcjonowaniem i oczekiwaniami wobec rodzin zastępczych oraz funkcjonowaniem instytucji mających zapewnić wsparcie oraz sprawować kontrolę nad daną rodziną zastępczą i szeroko pojętym dobrem dziecka.

Nowa ustawa zmienia zasadniczo dotychczas wypracowany system wspierania dziecka i rodziny. Niektórzy twierdzą, iż ustawa wprowadza „quasi-system” wydzielający wspieranie rodziny i pieczę zastępczą od systemu pomocy spo- 
łecznej, z jednoczesnym wykorzystaniem zasobów pomocy społecznej. Ustawodawca określił następujące formy rodzinnej pieczy zastępczej:

1) rodzina zastępcza, a do niej należą: spokrewniona, niezawodowa oraz zawodowa, w tym zawodowa pełniąca funkcję pogotowia rodzinnego i zawodowa specjalistyczna;

2) rodzinny dom dziecka.

Wprowadzenie przez ustawodawcę nowych form rodzinnej pieczy zastępczej doprowadziło do zmiany nazewnictwa i zasad funkcjonowania dotychczasowych rodzin zastępczych. Wymagało to wprowadzenia szkoleń, które umożliwiały przekwalifikowanie się rodzin i dostosowanie się do nowych uregulowań prawnych.

Odnosząc powyższe formy rodzinnej pieczy zastępczej do miasta Łodzi, dostrzec należy, iż jest to miasto, w którym obecnie jest największa liczba zawodowych rodzin zastępczych w Polsce. Jak pokazuje historia, w mieście tym już w latach 1925-1926 doszło do przełomu w tworzeniu instytucji rodziny zastępczej, dającego podstawy prawne, pedagogiczne i społeczne do wykształcenia nowej formy opieki nad osieroconym dzieckiem.

Oddawanie dzieci osamotnionych pod opiekę rodzinom obcym rozpoczęło się w Wydziale Opieki Społecznej Magistratu m. Łodzi jako konieczność życiowa. Już w lutym 1926 roku na posiedzeniu magistratu Łodzi zapadła uchwała, która dokładnie określała warunki stawiane opiekunom oraz zakres i formy pomocy dla rodzin zastępczych. Osoby, które chciały wziąć dzieci na wychowanie, musiały spełniać długą listę wymagań określonych przepisami. Przede wszystkim niemowlęta mogły być oddawane na wychowanie osobom posiadającym własne, odpowiednie mieszkanie. Rodzice zastępczy winni być zdrowi „na ciele i umyśle” i najważniejsze powinny być to ludzie, którzy z zamiłowaniem oddadzą się sprawie wychowania dziecka i otoczą je należną opieką [Majewska 1948: 15].

Już wtedy piecza zastępcza była oparta na odpowiednim doborze rodzin i właściwej kontroli sprawowanej przez kompetentnego pracownika [Kusio 1998: 32-33]. Odnosząc się do najnowszych danych dotyczących miasta Łodzi z końca 2013 roku należy podkreślić, iż choć liczba rodzin zastępczych jest tu relatywnie duża, to zdaniem lokalnych ekspertów jest ona nadal niewystarczająca, aby wspomóc wszystkie dzieci oczekujące na prawidłowo działający rodzinny dom. Z danych uzyskanych z Łódzkiego Wydziału Wspierania Rodzinnej Pieczy Zastępczej wynika, że 30 listopada 2013 roku było 1041 rodzin zastępczych. Nadal najwięcej jest rodzin spokrewnionych z dzieckiem (704 rodzin). Rodzin zastępczych niezawodowych było 285. Na szczególną uwagę oraz pogłębione badania, które są w trakcie realizacji, zasługuje liczba rodzin 
zastępczych zawodowych, których pod koniec roku 2013 było w Łodzi 52 . Wśród zawodowych rodzin zastępczych dominują pełniące funkcję pogotowia rodzinnego - łącznie to 24 rodziny, następnie są rodziny zastępcze zawodowe - „zwykłe” (16 rodzin). Kolejne to rodziny zastępcze zawodowe specjalistyczne (11). Na terenie miasta Łodzi znajduje się 9 rodzinnych domów dziecka. Liczba rodzin zastępczych pozostaje zapewne w związku $\mathrm{z}$ dużym zapotrzebowaniem na ich usługi, co oznacza równocześnie, że problem zaniedbywania dzieci jest w Łodzi znaczący. Jak wskazują badacze zajmujący się tematyką rodziny, wśród głównych przyczyn utraty przez dziecko naturalnego środowiska rodziny własnej, mimo jej formalnego posiadania to najczęściej [Jakubowski 1977: 21]:

- zawężenie funkcji opiekuńczej rodziny (dziecko zaniedbane);

- rozbicie więzi uczuciowo-rodzinnej (dziecko odrzucone przez rodzinę);

- demoralizacja środowiska rodzinnego (dziecko przymusowo zabrane);

- dezintegracja strukturalna rodziny (dziecko opuszczone).

Rodzina zastępcza jest szansą powrotu dziecka do rodziny naturalnej. Pojęcie „szansa” oznacza „możliwość powodzenia w jakiejś sprawie lub zaistnienia jakichś pożądanych okoliczności” [http://sjp.pwn.pl 03.02.2014]. Odnosząc powyższe stwierdzenie do sytuacji rodzinnej dziecka oraz rodziny zastępczej początkowo wymaga się odłączenia dziecka od jego naturalnej rodziny własnej z uwagi na utratę przez dziecko naturalnego środowiska rodziny własnej, a przede wszystkim $z$ uwagi na zaburzenia więzi wzajemnej między dzieckiem a jego rodzicami. Rodzina zastępcza jest zatem szansą dla dziecka na budowanie pozytywnych relacji i uczenie się prawidłowych zachowań społecznych, a z drugiej strony stwarza możliwość poprawy sytuacji w domu rodzinnym. Jest to swego rodzaju „próba”, której poddani są rodzice biologiczni, czas dany na zrozumienie własnych błędów oraz dobrowolne poddanie się terapii, leczeniu, które mają na celu uświadomienie rodzicom popełnianych pomyłek i błędów. Intencją tej pracy jest reintegracja rodziny. Pojęcie reintegracji rodziny oznacza

planowy proces odbudowywania więzi w rodzinach, w których na skutek kryzysu więzi te zostały zerwane lub nadwerężone - od udzielenia informacji, nawiązania i podtrzymywania kontaktu do faktycznego powrotu dziecka do rodziny biologicznej [Stelmaszuk 1998: 108].

Rodzice zastępczy podkreślają ważność pomocy zarówno dzieciom, jak i biologicznym rodzicom w dążeniu do reintegracji rodziny biologicznej dziecka.

Te służby, które powinny działać i współdziałać, czyli Sądy, MOPS-y, GOPR-y, PCPR-y, no niestety ta współpraca nie idzie tak jak potrzeba, stąd też dzieci miesz- 
kają ze mną zamiast mieszkać z rodzicami, gdzie jest to po pierwsze dla wychowania dzieci tragedia, bo każde zerwane więzi nawet w takiej rodzinie która kuleje... czasami oczywiście trzeba zabrać dziecko, bo jest tak źle, ale w wielu przypadkach można by było tego uniknąć. Można by wspomóc rodzinę, nauczyć rodziców pisać. My mieliśmy rodziców, którzy byli analfabetami i zabierali im dzieci, bo na przykład nie potrafili wywiązywać się z tego co im pracownik socjalny mówił, dlatego że oni nie potrafili złożyć prostego papieru, a wstydzili się przyznać. A właśnie ten system tak powinien działać, że tam jest ktoś kto jest przyjacielem rodziny. Ten asystent, który idzie i pomaga. Jeżeli się źle dzieje, to on faktycznie powinien zareagować, bo jest też osobą, która według systemu odpowiada za tą rodzinę, ale powinien pomagać napisać pismo, podpowiedzieć na jaki kurs można iść, powiedzieć na przykład jak ugotować zupę pomidorową takie proste rzeczy. Wtedy dzieci nie musiałyby mieszkać ze mną i nie kosztowałyby tyle państwa. (05.13.KB)

Praca na rzecz wsparcia dziecka i rodziny powinna mieć charakter zespołowy. Współpraca instytucji mająca na celu koordynację różnych działań podejmowanych w celu reintegracji rodziny, a przede wszystkim praca ukierunkowana na zapewnienie stabilnego życia dziecku prowadzona przez edukację i kształtowanie postaw rodziców zastępczych i osób współpracujących na rzecz powrotu dziecka do rodziny naturalnej. „Pozyskiwanie, przygotowanie i wspieranie rodzin zastępczych to główne etapy i jednocześnie filary działań w reformowanym systemie opieki nad dzieckiem, gdzie edukacja jest podstawą każdego z nich" [Joachimowska 2002: 123]. Jednym z najważniejszych elementów w edukacji rodziców zastępczych jest uświadomienie tymczasowości sprawowanej opieki nad dziećmi. Wydaje się, iż jest to najbardziej problematyczna kwestia, a jednocześnie nieunikniona jest akceptacja tego warunku. Rodzice zastępczy traktują często swoją rolę rodzica jako misję, która ma na celu ochronę dziecka przed złem, którego dziecko wcześniej doświadczyło. Tym zachowaniem poniekąd zamyka się furtkę do ponownego połączenia i reintegracji rodziny. Jak stwierdza jeden z twórców polskiej pedagogiki A. Kamiński, dla dzieci

rodzina jest podstawowym zespołem wspólnoty życia, przede wszystkim wspólnoty emocjonalnej, w której przechodzą one proces przystosowania się, ułatwiający współżycie, kształtują na skutek relacji całą swą osobowość, odprężają się, a dla wielu osób rodzina, jej intymność uczuciowa, wspólnie przeżywane doświadczenia stają się podporą emocjonalną, ostoją bezpieczeństwa psychicznego [Kamiński 1972: 81].

Lokalne wsparcie służb społecznych, organizowanie szkoleń mających na celu przełamanie barier i otwarcie się na kontakt z rodzicami biologicznymi jest szansą dla dziecka na zrozumienie swojej osobowości i projektowanie własnej tożsamości bez poczucia żalu wobec obydwu stron - rodziców biologicznych, a także relacji z rodzicami zastępczymi. Trudno jest bowiem jednoznacznie 
wskazać granicę pomiędzy sferą zadań należących do rodziny naturalnej i sferą zadań należących do rodziny zastępczej [Safjan 1982: 168].

Bycie rodzicem zastępczym jest również szansą dla samych kandydatów do pełnienia tej roli na zrozumienie sensu własnego życia, dążeń i pragnień. Już na etapie szkoleń kandydat przepracowuje własne predyspozycje do pełnienia tej trudnej i ważnej funkcji. Sprawdza samego siebie. Dlatego tak istotne jest, aby dobrze przygotować rodziców zastępczych do funkcjonowania w zupełnie nowych warunkach, z którymi dotychczas nie mieli do czynienia.

Dobrze przygotowana tzn. w pełni świadoma zjawiska czasowości swojej roli i związanych z nią emocji. Opiekunowie zastępczy muszą znać cele interwencji i uświadamiać sobie, w jakim kierunku ona zmierza. Niezbędne jest więc ich ciągłe wspieranie i współpraca ze specjalistami [Joachimowska 2002: 124].

Rodzice zastępczy pomimo tego, iż nie mogą być w pełni rodzicami dla przyjętych pod opiekę dzieci, starają się wypełniać role jak prawdziwi rodzice, $\mathrm{z}$ wielkim zaangażowaniem i szacunkiem wobec dziecka, bo, jak mówią, to jest ich zadanie.

Jestem rodzicem zastępczym, bo zastępuję rodziców i tego się inaczej nie da nazwać. Nie jestem rodzicem tak naprawdę, nie jestem rodziną tak, więc możemy do każdego słowa i do każdej litery się przyczepiać, a jakoś to trzeba nazwać. A rodzic zastępczy, to też to jasno mówi, że ktoś kto zastępuje rodzica w pewien sposób, bo tak niestety się dzieje. To my siedzimy z dziećmi w szpitalach jeżeli dzieci są chore, czasami jedziemy na pogotowie. My ich bronimy w szkole, my kłócimy się z nauczycielami, my wychowujemy - zastępujemy rodziców no nie inaczej... (05.13.KB)

W sytuacji, gdy dziecko jest umieszczone w rodzinie zastępczej, a rodzice biologiczni dziecka przeżywają trudności we własnym życiu, nie są wydolni wychowawczo należy być otwartym na kontakty z rodzicami biologicznymi i rodzeństwem, gdyż wpływają one na adaptację dziecka do nowego otoczenia i jego rozwój emocjonalny, nawet, gdy rodzice mają trudności we własnym życiu [Stelmaszuk 2000: 83-85]. Utrzymywanie kontaktów z rodzicami biologicznymi dziecka przebywającego w rodzinie zastępczej można postrzegać jako szansę na głębsze poznanie dziecka, jego sytuacji osobistej. Jest też szansą dla rodziny biologicznej na odbudowanie relacji z dzieckiem i reintegrację rodziny, choć niekiedy niesie ze sobą różne przeszkody (bariery) w realizacji roli rodzica zastępczego. Istnieją sytuacje, w których to dzieci są oszukiwane przez własnych rodziców. Rodzice biologiczni często nie dotrzymują obietnic składanych dzieciom. Zdarzają się również donosy i skargi od rodziców biologicznych kierowane pod adresem rodziców zastępczych. 
W naszej historii mieliśmy cały wachlarz różnych kontaktów od rodziców którzy byli wspierający, którzy słuchali, uczyli się, prosili o pomoc. Potrafili jakby współpracować i odzyskiwali dzieci...Przez ostatnie 4 lata 12 dzieci od nas wróciło do rodzin biologicznych. Jedna mama kiedy zwracaliśmy jej uwagę na sposób kontaktu z córką i na sposób zachowywania się - doniosła na nas. Prawda jednak jest taka, że jeżeli nie mamy kontaktu z rodzicami, to nigdy się nie dowiemy wszystkiego o dziecku. (05.13.KB)

Rodzina stanowi przez całe życie układ odniesienia i podstawową przesłankę własnej tożsamości, jest dowodem przynależności i ukierunkowania własnej samorealizacji na drodze życiowej [Winiarski 2000: 130].

Gdy dziecko zostaje umieszczone w rodzinie zastępczej, dochodzi do uruchomienia w jednym czasie trzech procesów. Są to: separacja od rodziny własnej, przejście do rodziny zastępczej i włączenie w nowy system rodziny. Sytuacja ta powoduje powstanie wielu emocji: poczucie osamotnienia, opuszczenia, winy, smutek, wrogość, lęk o przetrwanie oraz wstyd [Stelmaszuk 2000: 83-85]. Dlatego też odpowiednie przygotowanie rodziców zastępczych odgrywa bardzo ważną rolę. Ich możliwość umiejętnego zmagania się z różnorodnym wachlarzem emocji i adekwatnego reagowania na nie wpływa na szybszą asymilację dziecka, jak również rodziców zastępczych do nowej sytuacji. Rozwój rodziców zastępczych, ich ciągła edukacja, uczestnictwo w szkoleniach prowadzonych przez wykwalifikowanych trenerów prowadzą do zwiększania świadomości i umiejętności w pracy z dzieckiem z różnymi potrzebami i problemami. Rodzice zastępczy podkreślają chęć uczestnictwa w większej liczbie szkoleń i edukacji.

Przydałoby się...być może dla chętnych w jakiś sposób żeby ludzie mogli przegadać, przemyśleć siebie i swoje postępowanie. A dla kandydatów na rodziców zastępczych 10 spotkań po 3 godziny, to jest zbyt mało. Tak naprawdę sukces zależy od tego, to jest wszechobecne, że ludzie nie potrafią nazywać swoich uczuć. Jeżeli sami nie potrafią nazywać swoich uczuć, to jak mogą nazwać uczucia dzieci, które mają wychowywać. Jak mają odkrywać, to co jest zakryte pod warstwami niemiłych doświadczeń, albo jakiś krzywd, które się gromadzą. Pytanie: komu chcemy zrobić dobrze? Czy chcemy mieć jakiś papierek o ukończeniu kursu, czy faktycznie chcemy się czuć przygotowani do pełnienia roli rodzica zastępczego, a to nie jest to samo co być zwyczajnym rodzicem. (05.13. KB)

Wprowadzenie konieczności opracowywania planów pracy z rodziną, planów pomocy dziecku umieszczonemu w pieczy zastępczej, ocena sytuacji dziecka w celu reagowania na nieprawidłowości mogące pojawić się w danej rodzinie zastępczej, ocena rodziny zastępczej mająca na celu wyeliminowanie 
rodzin niespełniających właściwie swojej funkcji, dają większą pewność na niedopuszczanie do zaniechań i zachowań wpływających destrukcyjnie na dobro i życie dziecka. Dlatego tak istotne jest podejmowanie różnych lokalnych i ponadlokalnych inicjatyw popartych działaniami ukierunkowanymi na budowanie współpracy służb publicznych. Zorganizowanie rodziny jest przecież punktem wyjścia do jej prawidłowego funkcjonowania w przyszłości. Bardzo ważne jest to, aby rodzice zastępczy byli aktywni w swoim działaniu i sami poszukiwali różnych rozwiązań, a przede wszystkim powinni działać tak, aby zapewnić jak najlepszy rozwój dziecka. Podejmowanie takich inicjatyw przejawiać się może w tworzeniu stowarzyszeń i fundacji na rzecz dzieci, młodzieży i rodzin, które przez swoje zaangażowanie tworzą sieci wsparcia. W konsekwencji podejmowanych działań tworzą się więzi oraz wzajemna współpraca i pomoc na rzecz dziecka i rodziny. Przykładami podejmowania działalności na rzecz rodzicielstwa zastępczego w Łodzi są Fundacja Rodzinnej Opieki Zastępczej Ja i Mój Dom oraz Łódzki Oddział Stowarzyszenia Zastępczego Rodzicielstwa. Do zadań Fundacji należy przede wszystkim organizacyjne i materialne wspieranie rodzin zastępczych i rodzinnych domów dziecka w zakresie: opieki zastępczej, opieki medycznej i psychologicznej, zdobywania wykształcenia, usamodzielnienia wychowanków, wypoczynku wakacyjnego, przeciwdziałania uzależnieniom i bezrobociu. Fundacja zajmuje się ponadto organizowaniem współpracy i wzajemnej pomocy między zastępczymi rodzicami przez: wspieranie samopomocowych grup rodzin zastępczych, szkolenia i warsztaty dla rodzin zastępczych i biologicznych, a także poszukiwanie kontaktów z krajowymi i zagranicznymi środowiskami dla dzieci osieroconych i odrzuconych. Tworzenie systemu wsparcia dla rodzin zastępczych i biologicznych oraz usamodzielnionych wychowanków jest szansą dla rodziców jak i dorastających dzieci na zrozumienie własnych potrzeb, błędów oraz celów życiowych [www.ja-i-moj-dom.jasky.pl 04.02.2014]. Jest to jeden z niewielu przykładów podejmowanych działań. Podejmowane inicjatywy składają się na budowanie wspólnoty, budowanie więzi międzyludzkich. Uruchamianie sieci wsparcia w środowisku lokalnym jest przeciwwagą na osamotnienie rodziny zastępczej. Dostrzeganie ich, korzystanie z jej zasobów i sił społecznych zwiększa aktywność rodzin zastępczych, dzięki czemu nie czują się osamotnione, nie odczuwają braku poczucia wsparcia, wspólnoty i uznania [Joachimowska 2003: 692]. Propagowanie rodzicielstwa zastępczego, pokazywanie działalności fundacji, stowarzyszeń, a także pojedynczych oddolnych inicjatyw zwiększa zaufanie i otwartość społeczną na tego typu działania. Przyczynia się to do budowania wspólnoty demokratycznej, przyjmowania czynnej, aktywnej postawy wobec zaniedbywania i łamania praw dziecka i rodziny. Dzięki tym inicjatywom przełamywane są 
bariery i stereotypy dotyczące rodzicielstwa zastępczego, a jednocześnie powstają nowe szanse, które prowadzą do zwiększenia zainteresowania rodzicielstwem zastępczym.

Ustawa, która weszła w życie 1 stycznia 2012 roku wprowadza nowe rozwiązania mające na celu wsparcie rodzin zastępczych. Do rozwiązań tych należy także wprowadzenie formy rodziny pomocowej, która przysługuje rodzinom zastępczym w sytuacjach czasowego niesprawowania opieki nad powierzonymi dziećmi. Rodzicom zastępczym przysługuje 30-dniowy wymiar wypoczynku w ciągu roku, udział w szkoleniach, czy też pobyt w szpitalu, a także w sytuacjach nieprzewidzianych trudności lub zdarzeń losowych. Wtedy też rodzina pomocowa służy wsparciem i przejmuje opiekę nad dziećmi. Zdaniem rodziców zastępczych zbyt długa procedura organizacji opieki nad dziećmi powiązana z niepewnością, czy osoby pozostające i odpowiadające za dzieci podczas nieobecności rodziców zastępczych prawidłowo wywiążą się z przydzielonego im zadania, wpływa na to, iż w konsekwencji prawo to nie jest do końca realizowane przez rodziców zastępczych ze względu na dobro i bezpieczeństwo dzieci.

Trzy razy w ciągu 11 lat udało się nam być na urlopie samemu. Czasami jesteśmy po połowie. To nie jest kwestia ustawy, to jakby głównym problemem jest kwestia organizacji tego kto nas zastąpi, bo tutaj trzeba być non stop czujnym, trzeba mieć ogromne poczucie uwagi, trzeba wykonywać jednocześnie kilkanaście różnych zawodów, trzeba mieć nasze zaufanie, że się czegoś nie zepsuje. Czasami jest tak, że jak my wyjeżdżamy, to na nasze miejsce wchodzi 6 osób żeby to ogarnąć. My siedzimy już w tym bardzo długo i mamy wyrobiony system, my wiele rzeczy robimy po drodze. Wstając od siebie z pokoju idąc do kuchni po drodze wykonujemy kilka rzeczy. Nie musimy specjalnie tego planować, rozpisywać, poza tym wiemy kiedy dzieci coś kombinują, kiedy bardziej trzeba być czujnym, kiedy możemy przystopować, a na co położyć większy nacisk. (05.13.KB)

Ustawodawca powołuje również nową rolę $\mathrm{w}$ ustawie o wspieraniu rodziny i systemie pieczy zastępczej; jest to rola koordynatora pieczy zastępczej. Do jego zadań należy przede wszystkim monitorowanie rodzin zastępczych. Celem tego nadzoru jest pomoc w pracy $\mathrm{z}$ rodziną biologiczną, wspólne poszukiwanie specjalistycznego wsparcia dla dzieci z problemami zdrowotnymi, jak również zgłaszanie do ośrodków adopcyjnych dzieci z uregulowaną sytuacją prawną. Stała kontrola i ocenianie opieki nad dziećmi ma na celu przede wszystkim bezpieczeństwo dziecka i wyeliminowanie sytuacji, które mogłyby doprowadzić do kryzysu rodziny zastępczej, a w konsekwencji do jej odwołania. Ciągła obserwacja zachowań i weryfikacja funkcjonowania rodziny zastępczej wpływa na odczuwanie przez rodziców inwigilacji i często wzbudza niepokój. 
Mam świadomość, że ponoszę bardzo duże koszty, których nikt mi nie zwróci. W sensie odsunięcia jakiś swoich potrzeb, podporządkowania się, stresów, bo ja nie wiem z której strony będzie próbował ktoś mnie przyatakować. Nas się stawia w takiej pozycji tłumacz się, broń się i pilnuj się. (03.12.KB)

Na większość działań, które podejmuje człowiek składa się także poniesienie strat w wyniku uzyskania określonych zasobów. Zwykle musi upłynąć pewien czas, aby dostrzec bilans poniesionych zysków i strat. Tak też dzieje się w sytuacji rodzicielstwa zastępczego. Powstałe szanse generują wiele barier, które często powodują utrudnienia, ograniczenia w pełnieniu roli rodzica zastępczego. Pojawia się wtedy pytanie - czy wytrwam w tej roli? Niewątpliwie odbiór społeczny, wsparcie lokalne, które prowadzi do zrozumienia i wzmocnienia roli rodzica zastępczego jest sposobnością do kształtowania trwałej i stabilnej roli opiekuna zastępczego.

Nowa ustawa nakłada na wszystkie szczeble samorządu terytorialnego (gminę, powiat, województwo) zadania związane z jej wykonywaniem. Gminy mają obowiązek współfinansowania pieczy zastępczej. Gmina właściwa ze względu na zamieszkanie dziecka pozbawionego opieki rodzicielskiej będzie wraz z powiatem ponosić koszty jego pobytu w placówkach opiekuńczo-wychowawczych, rodzinnych domach dziecka i rodzinach zastępczych. Dotychczas wszystkie zadania związane $\mathrm{z}$ rodzicielstwem zastępczym, prowadzeniem placówek opiekuńczo-wychowawczych, ośrodków adopcyjno-opiekuńczych było przyporządkowane zadaniom własnym powiatów (powiatowym centrom pomocy rodzinie). Niewątpliwie największa bariera wynika ze zmian, które wprowadza ustawa. Obarczenie samorządów gminnych, powiatowych nowymi zadaniami zwiększy koszty, co może negatywnie wpływać na jakość wykonywanych funkcji.

Rodzice zastępczy sprawujący pieczę zastępczą nad dzieckiem, które ma ograniczoną lub zawieszoną władzę rodzicielską również są pozbawieni komfortu psychicznego, który wpływa na prawidłowe wywiązywanie się z roli rodzica zastępczego. Dziecko bowiem w każdej chwili może powrócić do pieczy zastępczej, co nie wpływa korzystnie na sytuację dziecka i często jest źródłem wielu tragedii. Dziecko raz odrzucone, zagubione odczuje to jako kolejną krzywdę. Dlatego tak ważne jest to, aby rodzice zastępczy w podejmowanych działaniach unikali przymusu i kalkulacji, gdyż dziecko jest na to bardzo wrażliwe i może odebrać dany komunikat z odwrotnym skutkiem. Oczekuje się, że opieka i wychowanie będą płynąć z troski i miłości, a nie ze współczucia, litości i źle pojętego obowiązku [Kusio 1998: 77]. 
Celem szkoleń prowadzonych dla kandydatów na rodziny zastępcze jest edukacja kandydatów oraz rodziców zastępczych oparta na programach szkoleniowych, które pozwalają przyjmować normy zawarte w założeniach systemu opieki nad dzieckiem poprzez zrozumienie i ich akceptację, na zasadzie dyskursu, a nie poprzez ich narzucenie i konieczność podporządkowania się. Zrozumienie, zaakceptowanie i w efekcie zinternalizowanie wartości więzi dziecka z rodziną pochodzenia oraz wartości współpracy muszą być podstawami do otrzymania certyfikatu odbycia szkolenia w zakresie opieki zastępczej. Taka powinna być główna idea dotycząca formy i treści szkoleń [Joachimowska 2008: 84].

To dzięki szkoleniom rodzice zastępczy mogą dowiedzieć się, jak pracować z dzieckiem, jak wspierać jego rozwój, jak radzić sobie w trudnych sytuacjach i gdzie szukać wsparcia, a przede wszystkim dogłębnie poznają istotę rodzicielstwa zastępczego.

Zapewnienie właściwej formy pomocy jest powiązane ze ścisłą współpracą pomiędzy instytucjami, rodzinami, a także alternatywnymi formami pomocy. Każda forma opieki powinna być postrzegana jako współzależna i nawzajem się dopełniająca. Należy zadbać o to, aby opiekunowie byli odpowiednio przygotowani do pełnienia roli rodzica zastępczego poprzez szkolenia, wspierani w podejmowanych działaniach i adekwatnie wynagradzani za usługi, jakie świadczą [Colton 2001: 180]. Umożliwia to podjęcie nie tylko nowej roli profesjonalnego rodzica zastępczego, ale także stworzenia nowej grupy zawodowej - profesjonalnych wychowawców świadczących opiekę nad dziećmi we własnym domu. W myśl nowej ustawy, która proponuje nowe warianty rodzin zawodowych jak: „specjalistyczne”, „o charakterze pogotowia rodzinnego”, czy też „rodzinne domy dziecka" stwarza szansę na zapewnienie opieki dzieciom o zróżnicowanych potrzebach. Jest jednocześnie szansą na rozpoczęcie autentycznej współpracy między profesjonalistami i użytkownikami systemu, której ideą jest objęcie dziecka opieką służb społecznych niebędące karą za błędy popełnione przez rodziców ani złe zachowanie dziecka, ale realizacją prawa dziecka i rodziny do wspierającej pomocy i opieki [Stelmaszuk 2005: 104].

Celem szeroko rozumianej polityki społecznej działającej na rzecz dziecka i rodziny w Polsce powinno stać się otwieranie społeczeństwa na problemy dotyczące podstawowej komórki, jaką jest rodzina tak poprzez tworzenie nowych rodzin zastępczych, jak i respektowanie prawa rodziców do wychowywania swoich dzieci, nie naruszając przy tym godności dziecka. Wszystkim tym działaniom towarzyszyć winno partnerskie podejście do wypracowania standardów i poprawy jakości podejmowanych działań w służbie dziecku i rodzinie. 


\section{Bibliografia}

Andrzejewski M. (1999), Prawna ochrona rodziny, Warszawa

Colton M. (2001), Tendencje w opiece zastępczej, [w:] Z. Stelmaszuk (red.), Zmiany w systemie opieki nad dziećmi i młodzieża - perspektywa europejska, Katowice

Jakubowski M. (1977), Podstawowe pojęcia, przedmiot i zadania pedagogiki opiekuńczej, [w:] Pedagogika opiekuńcza. Materiały z krajowej konferencji Komitetu Nauk Pedagogicznych PAN, Warszawa

Jamrozik A., Nocella L. (2000), The sociology of social problems. Theoretical perspectives and methods of intervention, New York

Joachimowska M. (2008), Rodzicielstwo zastępcze. Idea-Problemy-Analizy-Kompetencje, Bydgoszcz

Joachimowska M. (2003), Rola edukacji rodzin zastępczych $w$ tworzeniu środowiskowych grup wsparcia, [w:] K. Marzec-Holka (red.), Pomoc społeczna - Praca Socjalna - Teoria i prakty$k a$ t. 2, Bydgoszcz

Joachimowska M. (2002), Rodzina zastępcza szansa powrotu dziecka do rodziny naturalnej, [w:] A. Radziewicz-Winnicki, E. Bielska (red.), Edukacja a życie codzienne, Katowice

Kamiński A. (1972), Funkcje pedagogiki społecznej, Warszawa

Kolankiewicz M. (red.), (1998), Zagrożone dzieciństwo. Rodzinne i instytucjonalne formy opieki, Warszawa

Kusio U. (1998), Rodzina zastępcza jako środowisko wychowawcze, Lublin

Majewska A. (1948), Rodziny zastępcze Łodzi, Łódź

Marzec-Holka K. (red.), (2003), Pomoc społeczna - Praca Socjalna - Teoria i praktyka, t. 2, Bydgoszcz

Radziewicz-Winnicki A., Bielska E. (red.) (2002), Edukacja a życie codzienne, Katowice

Safjan M. (1982), Instytucja rodzin zastepczych. Problemy prawno-organizacyjne, Warszawa

Stelmaszuk Z. (2000), Dziecko w rodzinie zastępczej, „Praca Socjalna” 2000, nr 3,

Stelmaszuk Z. (2001), (red.), Zmiany w systemie opieki nad dziećmi i młodzieża - perspektywa europejska, Katowice

Stelmaszuk Z. (2005), Rola i zadania służb społecznych ds. pomocy dziecku i rodzinie. Perspektywa europejska, [w:] M. Racław-Markowska (red.), Pomoc dzieciom i rodzinie w środowisku lokalnym, Warszawa

Stelmaszuk Z. (1998), Szanse reintegracji rodziny w systemie opieki nad dzieckiem, [w:] M. Kolankiewicz (red.), Zagrożone dzieciństwo. Rodzinne i instytucjonalne formy opieki, Warszawa

Warzywoda-Kruszyńska W. (red.) (2012), Bieda dzieci - Zaniedbanie - Wykluczenie społeczne, Łódź, Wydawnictwo Uniwersytetu Łódzkiego

Winiarski M. (2000), Rodzina - szkoła - środowisko lokalne. Problemy edukacji środowiskowej, Warszawa

Ustawa z dnia 9 czerwca 2011 roku o wspieraniu rodziny i systemie pieczy zastępczej (Dz. U. nr 149, poz. 887, z późn. zm.)

\section{Źródła internetowe}

www.ja-i-moj-dom.jasky.pl [04.02.2014]

http: //sjp.pwn.pl [03.02.2014] 


\section{SUMMARY}

\section{Barriers and Opportunities for Foster Parenting. Foster Family as a Recipe for Crisis?}

For one's proper maturation, every child needs a family which would provide him or her with care, love, food or shelter and would take care of his or her both emotional and educational development. When family is in crisis originating from different circumstances - not only the lack of functionality but also the illness or death of the parents, their lack of resourcefulness, the fact that they do not fulfill their parental duties in a right way, while the closest relatives are unable to take care of and help a childa very important role is played byintervention as well as institutional support and, above all, the placement of a defenseless child with a right foster family. The purpose of this article is to illustrate how foster families as well as institutions exercising control over the foster care system function after January 01, 2012 whenthe Act on Family Support and Foster Care System was introduced. The Act at hand is aimed at counteracting negative trends of removing children from their dysfunctional families in order to place them within the foster care system. The purpose of the Act is to reduce the number of children placed within the foster care system and to assure that the ones who have already been included into the system would be entrusted to foster families or placed in small environmental care facilities. Social work with dysfunctional family is now to be the basic instrument for acting in favor of a child. However, the introduction of this new Law raised many concerns and criticisms from institutions to which new roles and responsibilities were assigned and aroused the interest of existing foster families. A child leaving his or her home, often all of a sudden, feels very lonely, unwanted, and is forced to look after one's place in the world, acceptance, and understanding. The work carried out by foster families should then consist in rebuilding the child's self-esteem and his or her sense of belonging to a particular group and environment. It is a hard and time-consuming task which requires a lot of understanding and acceptance. Therefore, regular cooperation with different institutions which support both biological family - in restoring the appropriate way of fulfilling parental roles, as well as foster family, the aim of which is to assure the replacement of a child with his or her family of origin, is necessary. Promotion and development of the foster family care system have profound social and economic justification. It is one of the most effective and desirable ways of protecting and helping children who do not have "normal" and well-functioning families. The institution of a foster family becomes an 
asylum in which at child is to recover from ingrown traumaand rebuild his or her self-esteem.

\section{Keywords:}

foster family, family reintegration, assumptions of the Act on Family Support and Foster Care System, a child in a foster family, institutional cooperation and support 